\title{
REAL IMPROVEMENT PROCESSES IN THE ARMY BASED ON THE LEAN SIX SIGMA CONCEPT
}

\author{
Igor J. Epler ${ }^{a}$, Ranko C. Božičković ${ }^{b}$, \\ Slaviša N. Arsićc, Jelena B. Dinićd \\ a University of Defence in Belgrade, Military Academy, \\ Belgrade, Republic of Serbia, \\ e-mail: igor.epler@gmail.com, \\ ORCID iD: (i)http://orcid.org/0000-0002-1616-5139 \\ b University in East Sarajevo, Traffic Faculty, East Sarajevo, \\ Republic of Srpska, Bosnia and Herzegovina, \\ e-mail: bozickovicranko@gmail.com, \\ ORCID iD: (i)http://orcid.org//0000-0001-5519-5747 \\ c University of Defence in Belgrade, Military Academy, \\ Belgrade, Republic of Serbia, \\ e-mail: arsic.slavisa@gmail.com, \\ ORCID iD: (iDhttp://orcid.org/0000-0001-7431-7308 \\ ${ }^{d}$ University of Defence in Belgrade, Military Academy, \\ Belgrade, Republic of Serbia, \\ e-mail: jecika.maka@gmail.com, \\ ORCID iD: (iohttp://orcid.org/0000-0002-5179-829X,
}

DOI: $10.5937 /$ vojtehg64-8242

FIELD: Logistics (organization, economy, logistics management) ARTICLE TYPE: Professional Paper ARTICLE LANGUAGE: English

Abstract:

Readiness for challenge and change, doing more with less as well as focusing on quality and the customer - these are some of the most important areas of the activities of industrial producers, which military leaders in armies around the world have also developed to make their work more efficient and effective. This article provides an overview of the achievements in the United State of America (USA) military and its suppliers and associates, where the implementation of modern process management concepts has led to significant improvements and savings in various areas. The article also suggests possible applications of the existing successful business models in related areas in the Serbian Army.

Key words: lean, suppliers, military, manager, user, field. 


\section{Introduction}

Market competition, business conditions, contemporary problems, threats and trends - they all require changes in the ways of thinking and acting of entire nations, their governments, and large organizational systems which produce complex technical systems or provide a variety of services. Military systems are, by their own nature, large users of resources and services. They mostly possess production and service capacities that are often insufficient to cover their own needs, due to changes in the execution of planned or unexpected or complex tasks, so they have to meet their own needs by joining forces with respective systems or in the open market. Approved resources are, like everywhere, a limiting factor for the execution of tasks. The system's response to emerging changes and needs in a fast, complete and high-quality way has already become an imperative, which is particularly evident when it comes to organizational systems that deal with the defense of a country, its interests, territory and resources.

Management of processes in large organizational systems in the traditional manner (decrease the cycle time, more intensive and more dynamic work, recruiting, buying more machines, analysis of profits but not losses, planning without taking into account limitations, etc.) does not give satisfactory results in the modern time. Intellectual potentials of the Army, in cooperation with industry representatives and other civilian organizations, are trying to find a solution to this problem and manage to lead a fight for quality and customers to an extent, by observing and analyzing processes, encouraging and involving all members to make changes for the benefit of both the system and their own, as well as by creating and using the methods, techniques and tools that bring improvement.

This article is based on the theoretical assumptions of modern concepts of process management in organizational systems, which have found their implementation and have given very good results in large organizational systems dealing with production of technical systems (TS) and providing maintenance services to TS such as Toyota, Ford, Boeing and others. The article presents the historical development of the Lean and Six Sigma concepts of managing organizational systems, as well as the most commonly used ones in the last decades. The principles, methods, techniques and tools of these management concepts are presented. The differences between the traditional organizational systems and the Lean Six Sigma organizational systems are given as well as significant results which can be achieved by applying the Lean and Six Sigma concepts of managing organizational systems. Most of the article deals with the display and the analysis of the startup and implementation of Lean Six Sigma transformations in foreign armies, 
especially in the United States of America (USA) and the United Kingdom (UK), presenting all the potential possibilities of the application of the described conceptual approach through the implementation phases. At the end of the article, the basic management functions and processes in the Ministry of Defence (MoD) of the Republic of Serbia and the Army of Serbia are briefly analysed, with the aim of developing models to improve the situation on the basis of the Lean Six Sigma concepts, modeled on the described large systems in the USA and the UK.

\section{Business improvement based on contemporary concepts}

In order to survive in the market in contemporary business conditions, production and service systems have to focus on customers and strive to business excellence, especially in crisis conditions. A response to new circumstances imposed by market can be found in the Lean Six Sigma (LSS) concept management.

The Lean Six Sigma concept demands constant changes and continuous improvements. The emphasis is on employee involvement and teamwork, measurement and systematization of processes, reducing variations and defects and shortening the duration of the process.

The Lean Six Sigma concept has more advantages than other concepts of improvements. The concept of Six Sigma focuses more on process quality than process speed in the organizational system. The concept known as Lean is better at improving the rates of activity in the process than at improving quality.

The concept of Lean in technical and professional literature in the West first appeared in the early nineties of the twentieth century and is associated with the results of five years of extensive research which referred to the future of the automobile industry on a global level (John Krafcik, MIT student - now CEO Hyndaia). The Massachusetts Institute of Technology - MIT, USA, conducted research on the production system in the Japanese car factory Toyota, Toyota Production System (TPS), which was established under specific geographic, economic, political and cultural circumstances as an attempt to increase Toyota's competitiveness in the early 1950s and has continued to develop until today.

Books that stemmed as a result of this project represent real industry best-sellers (Figure 1) and they resulted in significant changes in the way how production is organized and viewed in the West.

The Lean management concept means to create greater values for customers or users with fewer resources invested. Lean companies know which values their customers or users require, and focus their key processes in a way to continuously add value to their customers or users. 


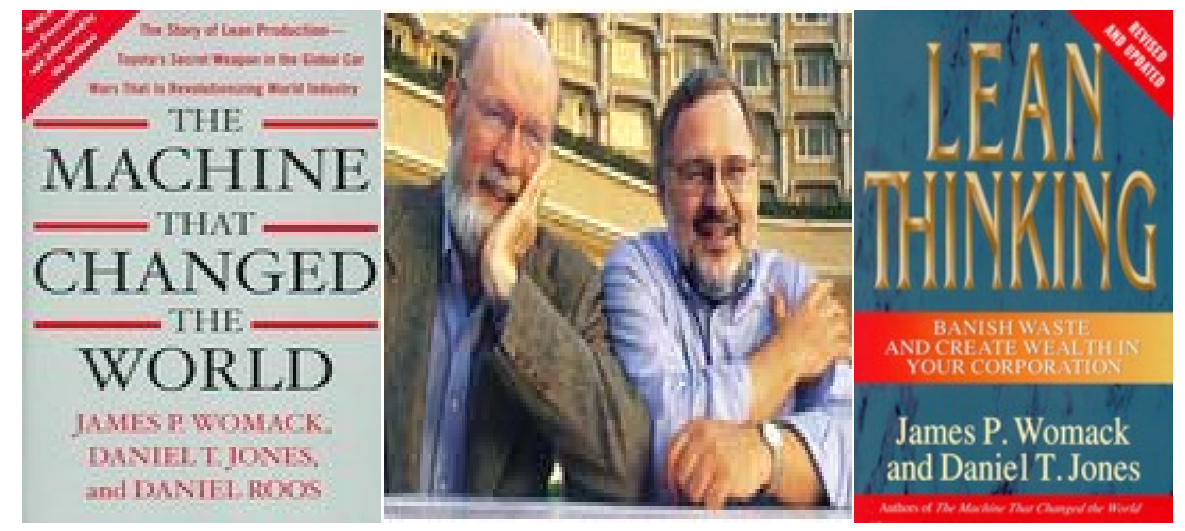

Figure 1 - Authors of books, James P. Womack and Daniel T. Jones Puc. 1 - Авторы книг, James P. Womack и Daniel T. Jones Slika 1 - Autori knjiga su James P. Womack i Daniel T. Jones

The concept of Lean means "slim" and vividly describes the concept basis: to produce or provide services with fewer supplies, facilities and defective products, with less capital, labor, hault, waiting and all that does not add value to a product or service. Lean production reduces unnecessary activities and is directed to the customer order.

The Lean concept is most easily described by its five basic principles: to determine the value for a customer or user, as illustrated by the message in Figure 2, to map a way to create a new value, to make a value flow, to establish that the flow meets the requirements (PULL or withdrawal) and to constantly strive for perfection.

Lean also defines eight losses: overproduction, waste, unnecessary movements, unnecessary supplies, excess processing, hold, transport, and insufficient use of the potential of employees.

In order to eliminate losses, Lean management uses its tools such as Kaizen, 5S, Kanban, value stream mapping, JIT, TPM and others.

With its tools, Lean achieves significant results, the most important ones being:

-Total production or service time is shortened;

- Increasing work performance;

-Reducing supplies;

- Improving quality;

-Reduced time of placing a product on the market;

- Smaller space requirements;

- Smaller investments in storage;

-Faster response to market changes;

-Simplifying the planning function and reduction of business documentation. 


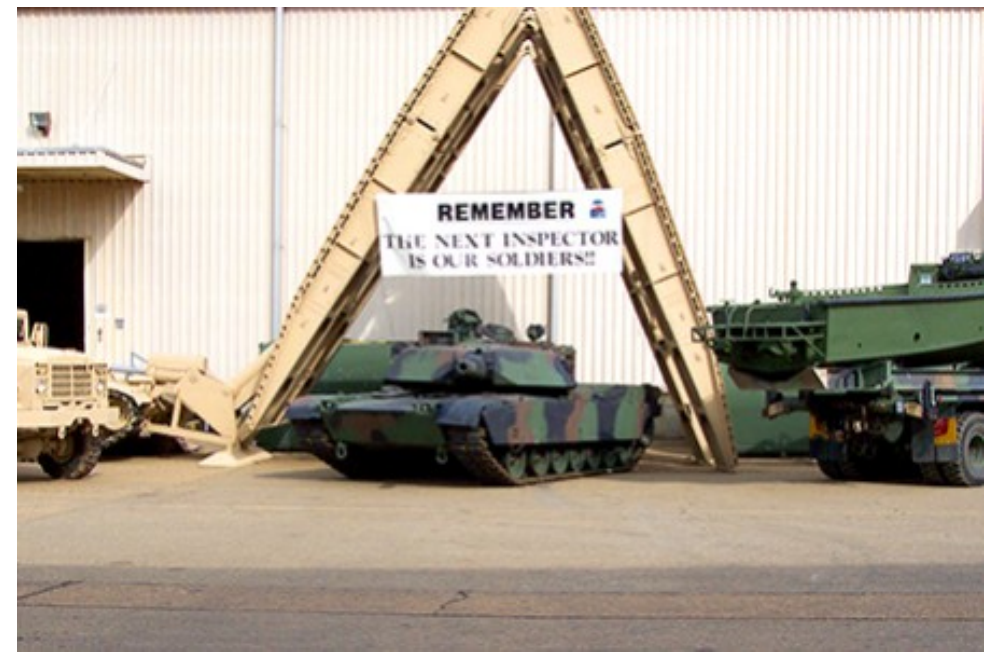

Figure 2 - A professional soldier needs a complete, functional and reliable combat vehicle

Puc. 2 - Для профессионального солдата важнее всего укомплектованность, исправность и надежность боевой машины

Slika 2 - Profesionalnom vojniku važno je samo da je borbeno vozilo ispravno, kompletno i pouzdano

The characteristic differences between Lean organizational systems and traditional organizational systems can best be seen in the following table (Rajković, 2012).

Table 1 - Difference between traditional and Lean organizational systems Таблица 1 - Отличия традиционной и Lean организационных систем Tabela 1 - Razlike između tradicionalnog i Lean organizacionog sistema

\begin{tabular}{|c|c|}
\hline $\begin{array}{l}\text { TRADITIONAL ORGANIZATIONAL } \\
\text { SYSTEM }\end{array}$ & LEAN ORGANIZATIONAL SYSTEM \\
\hline complex & simple \\
\hline Manages the budget & Is guided by demand \\
\hline excessive supplies & Supplies based on demand \\
\hline Accelerating activities that add value & $\begin{array}{l}\text { Finding and maximum reduction of } \\
\text { activities that do not add value }\end{array}$ \\
\hline $\begin{array}{l}\text { Mass production or provision of large } \\
\text { scale and small assortment }\end{array}$ & $\begin{array}{l}\text { Production of small series but more } \\
\text { models or the provision of various } \\
\text { services of a small scale }\end{array}$ \\
\hline Long time from order to delivery & The minimum time from order to delivery \\
\hline $\begin{array}{l}\text { Quality is based on inspection and } \\
\text { achieved by upgrade }\end{array}$ & $\begin{array}{l}\text { Quality is built into the design right from } \\
\text { the start }\end{array}$ \\
\hline Functional services & Process organization \\
\hline
\end{tabular}


The Six Sigma $(6 \sigma)$ is a business concept and method for quality improvement. The application of this concept began in the company for telecommunication devices and systems Motorola, in the 1980s. Thanks primarily to the successful implementation of the Six Sigma concept, in 1988 Motorola won the "Malcolm Baldrige Quality Award", the most famous American Quality Award (Goetsch, Davis, 2006). The application of this concept in organizational systems provides tools to make their processes more successful. The ultimate goal is to achieve zero defects in manufacturing some products, services or transactions. The $6 \sigma$ quality level corresponds to the appearance which is a variation equal to a half of the default tolerance, with the allowed deviation from the mean of 1.5 $\sigma$ (Figure 3) (Lazić, 2006).

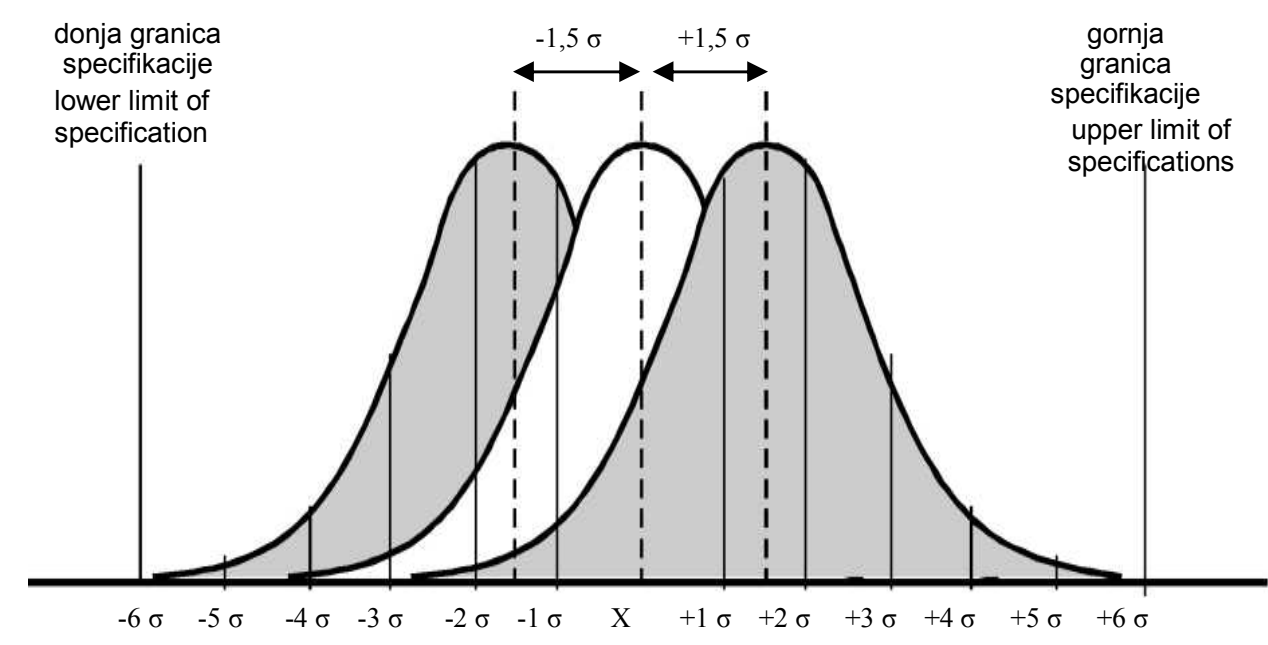

Figure 3-Dissipation of the process and the shift of the dissipation center Puc. 3 - Рассеивание процессов и перемещение центра рассеивания Slika 3 - Rasipanje procesa i pomeranje centra rasipanja

Allowing deviation from the mean is very important because there is no phenomenon occurring under perfect conditions. If the tolerance limits are set to the level of $+/-6 \sigma$ and the deviation from the mean value is allowed to be $+/-1.5 \sigma$, the level of product defects per million (DPM) will be from 3 to 4 defects. In Table 2 (Lazić, 2006), there are data for a process in which a deviation from the mean is not permitted and for a process with a permitted deviation of $1.5 \sigma$, typical for Motorola, where $\mathrm{Cp}$ is the precision index. 
Table 2 - The defect levels of centered and shifted processes Таблица 2 - Концентрация деффектов процессов центрирования и перемещения центра

Tabela 2 - Nivo defektnosti centriranih i pomerenih procesa

\begin{tabular}{|c|c|c|c|c|c|c|}
\hline \multirow{2}{*}{$\begin{array}{l}\text { The } \\
\text { tolerance } \\
\text { limits }\end{array}$} & \multicolumn{2}{|c|}{ Centered process } & \multicolumn{3}{|c|}{ The process shifted for the $\pm 1.5 \sigma$} & \multirow{2}{*}{ Cp } \\
\hline & Chance & dpm & Chance & dpm & Cpk & \\
\hline$\pm \sigma$ & 68.27 & 317.300 & 30.23 & 697.700 & & 0.33 \\
\hline $\pm 2 \sigma$ & 95.45 & 45.500 & 69.13 & 308.700 & 0.17 & 0.67 \\
\hline $\pm 3 \sigma$ & 99.73 & 2.700 & 93.32 & 66.680 & 0.50 & 1 \\
\hline $\pm 4 \sigma$ & 99.9937 & 63 & 99.379 & 6.210 & 0.83 & 1.33 \\
\hline $\pm 5 \sigma$ & 99.999943 & 0.57 & 99.9767 & 233 & 1.17 & 1.67 \\
\hline $\pm 6 \sigma$ & 99.9999998 & 0.002 & 99.99966 & $3-4$ & 1.5 & 2 \\
\hline
\end{tabular}

The application of the $6 \sigma$ concept showed a close relationship with financial results of companies. According to these results, companies, on the world scale, can be classified as world class, middle class and uncompetitive ones, as seen in Table 3 (Lazić, 2006).

Table 3 - The process capability impact on the competitiveness of companies Таблица 3 - Влияние процессов на конкурентоспособность компании Tabela 3 - Uticaj sposobnosti procesa na konkurentnu sposobnost kompanija

\begin{tabular}{|c||c||c|c||}
\hline $\begin{array}{c}\text { The tolerance } \\
\text { limits }\end{array}$ & $\begin{array}{c}\text { Number of defects per } \\
\text { million }\end{array}$ & $\begin{array}{c}\text { The price of low } \\
\text { quality }\end{array}$ & $\begin{array}{c}\text { The level of } \\
\text { competitiveness }\end{array}$ \\
\hline \hline $6 \sigma$ & 3.4 & $<10 \%$ OP & World Class \\
\hline $5 \sigma$ & 233 & $10-15 \%$ OP & \\
\hline $4 \sigma$ & 6,210 & $15-20 \%$ OP & Middle Class \\
\hline $3 \sigma$ & 66,680 & $20-30 \%$ OP & \\
\hline $2 \sigma$ & 308,700 & $30-40 \%$ OP & Uncompetitive \\
\hline $1 \sigma$ & 697,700 & & \\
\hline Note: OP - volume of sales & & \\
\hline
\end{tabular}

The $6 \sigma$ concept is not based so much on the number of defects per million opportunities, but rather on the process of gradually reducing the process dissipation. 


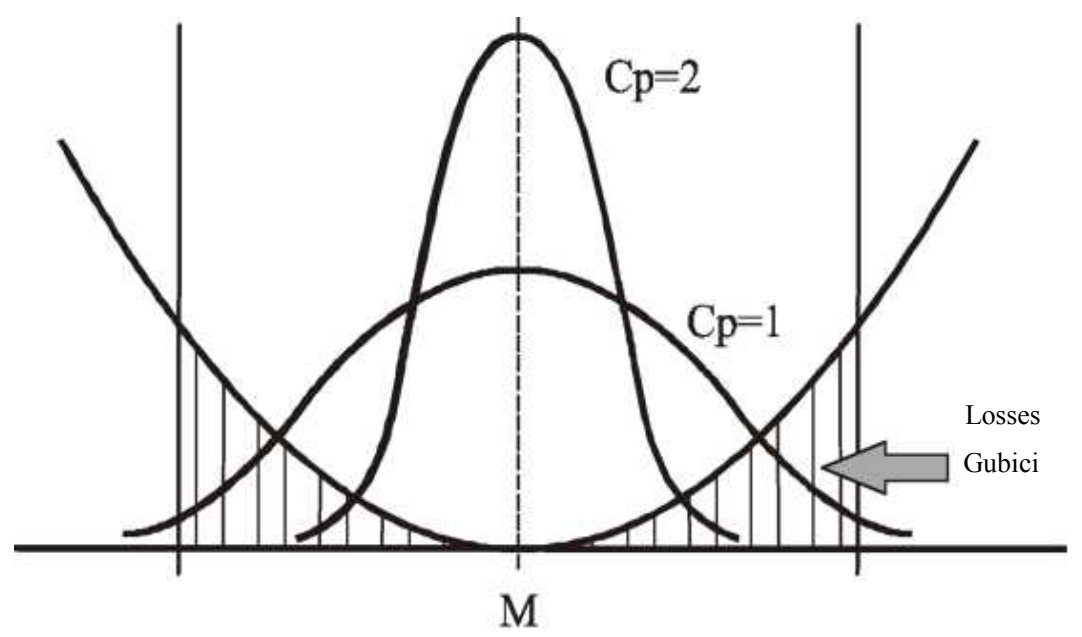

Figure 4 - Dissipation of the process and functions of losses Puc. 4 - Рассеивание процессов и функция потерь Slika 4 - Rasipanje procesa i funkcija gubitaka

In this way, losses are reduced and profits increased, which can be seen in Figure 4 (Lazić, 2006).

\section{Launching the Lean Six Sigma transformations in foreign armies}

\section{Support of the highest level of command}

As in private companies, at the very beginning of transformation processes, support of the army leadership and its engagement in educating and gaining support of employees is necessary for the continuity, of, above all, cultural changes.

The USA Air Force adopts the basics of the LSS concept through the entire organization. The Lean Six Sigma has expanded its functioning into three USA Air Force Logistics Centers (Robin, Tinker, Hill Air Force Bases (AFB)), where the Lean initiative brought exceptional improvements in the life cycle of processes and other key indicators (Wetekam, 2006) .

For example, various Rapid Improvement Events (RIEs) at the beginning of the 21st century in Robins AFB enabled employees to reduce the average C-5 USA military transport aircraft overhaul time from 339 days to fewer than 180 (Wetekam, 2006). It used to take more than $10 \%$ of that time or 39 days to carry out aircraft inspection or defectation before overhaul. The defectation time is today about 21 days. Although 
similar improvement was achieved in all these logistics centers, a lot of work still remained for potential future improvements. For this reason, AFB directors in charge of planning and programming have a permanent task to directly involve managers in Lean transformations.

\section{The need for cultural change}

In RAFB, the beginning of LSS transformations started by seeing the need to return to the Lean management concept from 1999, when Lean was shaped and recognized as a concept for significant improvements in industrial production by the MIT (Massachusetts Institute of Technology) specialists. In RAFB, they today learn to adapt and use TPS as the basis of the Lean concept, and to discover its real power. A look at the process that takes place in this organizational system is not a new one, but the whole process is involved in the PDCA (Plan, Do, Check, Act) cycle and continuous improvement. In addition, the strength of the Toyota Production System is properly understood not only as a process of thinking, but also as a way to consider a work process in an organizational system from the point of detection and elimination of losses.

\section{Mobilising resources in scientific work}

It is crucial to reduce aircraft overhaul time in all three Army Aviation Logistics Centers in the USA which deal with the highest level of aircraft maintenance, i.e. the task of top management is to get aircraft operational as soon as possible under the conditions of limited financial resources.

Every five to seven years, C-5 military transport aircraft are repaired at the highest level of maintenance. AFB workers dismantle them into pieces, and after necessary replacements, repairs and adjustments, they assemble them again. Every overhaul takes thousands of hours from the aircraft flight time. The introduction of the LSS concept in AFB, in the period from 2000 to 2006, saved more than 100 flight days to the US Air Force, by reducing the number of days aircraft spent in the repair shops for one third. In 2006, in RAFB, they achieved that $100 \%$ of the time needed for the $\mathrm{C}-5$ repair had $0 \%$ of changes in the overhaul schedule.

Analyzing numerous data related to C-5 aircraft (produced in 1960) maintenance is a complex job and scientific work. Scientific work is an area where the LSS concept has great potential. This is work that adds value to a product or service, during which significant information helps managers create a proper sense of when to use them, i.e. help them to make decisions based on real facts (Wetekam, 2006). 
Value Stream Mapping (VSM) is an essential LSS concept tool, necessary to be applied at the beginning of business improvement in the organizational system as well as later because of the need for continuous improvements of any process. VSM is primarily a help in analyzing and improving the flow of materials and information necessary for the production of products or the provision of services to customers or users. The need to apply initially VSM within scientific work does not seem logical to some scholars until they see the benefits of such an approach.

Scientific work involves asking questions and answering them. It is necessary to standardize questions in the right way to accomplish a specific task in a more efficient manner. For example, when purchasing a new weapons system, a panel discussion at the highest level of management should be conducted for each individual purchase. The panel should include a standard list of questions. Examples of panel applications during the acquisition or development of new weapons systems in the US Army are numerous. Only in this way functional technology can be designed, delivered and made suitable for future improvements.

A very important segment of scientific research in RAFB is the assessment of performed work as an important part of the process of strategic planning and budgeting in a 5-year period with the purpose of relentless pursuit and elimination of losses or activities that do not add value within the Lean system transformation. This is accomplished by observing how people perform individual activities, by eliminating weeks of lost time during task clarification and by wondering where to find additional gain. The RAFB leadership has a role to "clarify" the way in the introduction of Lean.

The management responsibilites and the problem solving methods are given in Table 4.

Table 4 - Responsibilities of the management and the problem solving methods (Wetekam, 2006)

Таблица 4 - Ответственность руководства и способы решения проблем (Wetekam, 2006)

Tabela 4 - Nadležnosti rukovodstva i načini rešavanja problema (Wetekam, 2006)

\begin{tabular}{|c|c|}
\hline \multicolumn{2}{|r|}{ RESPONSIBILITIES } \\
\hline $\begin{array}{l}\text { Deve } \\
\text { probl } \\
\text { possi }\end{array}$ & $\begin{array}{l}\text { ping an effective, sustainable development action plan that will solve the } \\
\text { ns identified in the phase of detecting the key cause and will eliminate a } \\
\text { lity of their return. }\end{array}$ \\
\hline \multicolumn{2}{|r|}{ SOLUTIONS } \\
\hline $\begin{array}{l}- \\
- \\
- \\
- \\
-\end{array}$ & $\begin{array}{l}\text { Creating a dual communication, } \\
\text { Developing a program of continuous self-control, } \\
\text { Emphasizing the need of harmonization with the directives and regulations, } \\
\text { Training to respect order and discipline, } \\
\text { Company policy must be complete, valid and consistent, } \\
\text { Standardization and harmonization of the control priorities on a weekly basis, }\end{array}$ \\
\hline
\end{tabular}




\title{
Realization of improvements in the army of the United States and the United Kingdom
}

\author{
Work on increasing flexibility and responsibility
}

As military targets are becoming more complex, fundamental changes are increasingly necessary. Missions such as, for example, destruction of an enemy's battalion clearly define the goal and the way of destruction. In these missions, unmanned reconnaissance vehicles are often used; however, they can be modified to carry missiles. The effect to be achieved is considered as well as necessary means for its realization. Lean, in this case, takes into consideration not only the elimination of losses, but also thinking about values and providing the necessary ones.

\section{Development of the organizational system horizontally}

Today, military environment requires more joint efforts and cooperation than ever before because of many activities to be carried out in complex conditions, for which multinational cooperation is often necessary.

In order to meet this demand, while working on improvements, the USA army has been adapting its organization from a vertical type of organisation to a more horizontal one, developing a network type of organisation of the LSS concept-based cooperation to become more effective. Developing a network cooperation, combined with the LSS transformation, enables creating a more effective and efficient system. Leaders must be firmly committed to change and need to talk about necessary changes from the lowest level in the organization. Subordinates need to understand the importance of the quality of their work. Acceptance of such work quickly returns through improving the quality of their work and they see improvements in their own workplaces.

\section{Application of the Lean Six Sigma concept under the condition of limited budget of the Navy of the United States}

A sense of necessity of transformation and greater readiness prevailed throughout the USA Navy, through increased involvement of personnel in the application of the LSS concept and through cultural 
changes for continuous improvement. The Naval Sea Systems Command (NAVSEA), together with the Program Executive Offices (PEOs), is responsible for the project of introducing the LSS in the USA Navy. Their role is to equip the Navy ships and their weapons systems and to ensure support throughout the entire life cycle. They develop, design, procure, overhaul, maintain, modernize and finally distribute vessels, platforms and appropriate weapons systems. They have the prescribed basic procedures and contracts to act upon with the support of government agencies for maintaining core competencies. This is the basis of high responsibility. The NAVSEA has about 50,000 government people, out of which about 27,000 work in four naval shipyards, about 19,000 work in eleven combat divisions, about 1,000 in four shipyard support entities and about 2,400 people in the headquarters. Their contracts also engage thousands of people in the industry. The NAVSEA / PEOs annual volume of business is around \$ 26 trillion, out of which $\$ 20$ billion goes to industry, and the rest to government employees. The budget of shipyards and the number of ships have declined since the end of the Cold War. The current USA fleet consists of 283 ships. The growth rate is around 4 ships a year. Admiral Mike Mullen, Chief of Naval Operations in the NAVSEA, aims to expand the national fleet of naval ships to 313 in 2015 (Wetekam, 2006). This formalized challenge (a long term plan) includes and unites all the resources (government and industry) and requires a transformation that will bring greater responsibility and assets for the existing budgets. For such an undertaking, it is necessary to coordinate 50,000 people working in the NAVSEA / PEOs, plus hundreds of thousands of others in the rest of the Navy, plus the contractors. These are enormous cultural changes that the Navy has been implementing for years. The biggest change to be brought by the application of the LSS management concept is an expectation that employees become inspired for necessary changes by their daily tasks, as the leadership reprograms the approved budget and learns how to be more efficient. The goal is to reach the level when people come up with new, more advanced ideas related to the job they do, from the top to the bottom. It is necessary to find a better and easier way to do things, by eliminating losses, improving quality, reducing discrepancies and avoiding bottlenecks and constraints. In this process, the key word is recapitalization (Wetekam, 2006).

The NAVSEA / PEOs apply the LSS tools in order to create value, learning how to look at a process from its beginning to the end and to make improvements. Some tools, such as VSM, have proven to be better than other LSS tools (Figure 6). 


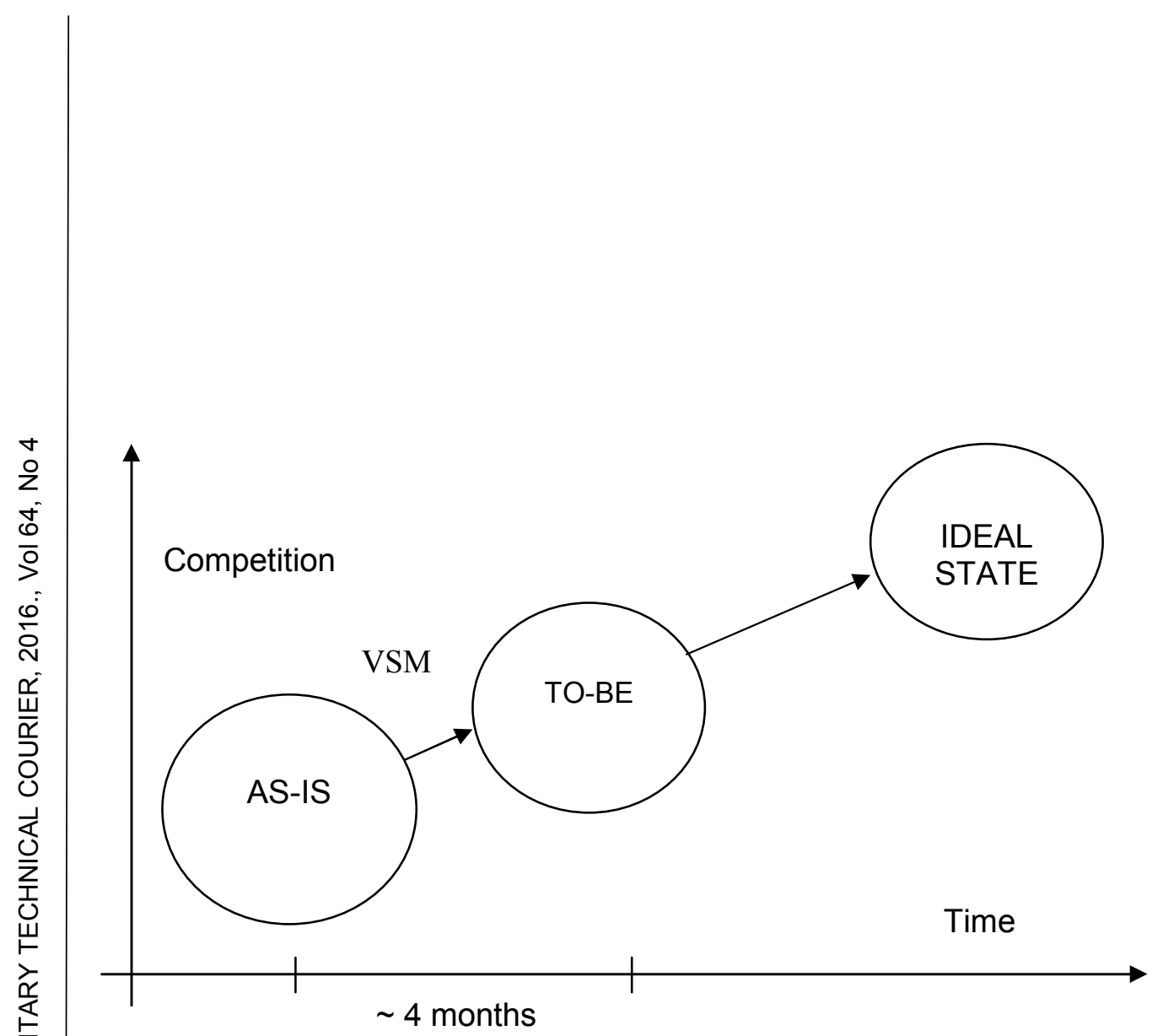

Figure 6-Mapping the flow of creating new values

Puc. 6 - Картирование течения создания новой ценности

Slika 6 - Mapiranje toka stvaranja nove vrednosti

The NAVSEA/PEOs argue that they are successful thanks to the constant application of the LSS basic principles (Wetekam, 2006):

- providing value to the user;

- making and analyzing the road map for creating value from one end of the organizational system to the other;

- making value creating journey without delay;

- enable the user to go to meet the created value (PULL);

- strive for perfection.

\section{The continuity of improvement until the maturity of the whole system}

The next step in NAVSEA is reaching a critical mass, i.e. encouraging more employees to take part in Lean events, individual cases within the company, by managers. They try to achieve the best utilization of the equipment and readiness in each of navy area activities.

In the Norfolk naval shipyard, the Lean transformation was carried out in the activities related to drydocking, ships, engine rooms, etc. What the user requests from the facility is to see how all these improvements in the shipyard are translated into finished work - preferably with more added value - on time and within the approved budget. This can save up to 1,000,000 \$. 
Significant improvements have been achieved in the field of reporting. They have developed VS reporting (reporting on the activities of organizing value creation streams). Instead of reporting on 1,000 Lean events, events are grouped according to their types. The Naval Aviation Facility was the first to do that. Requirements for achieving the same level spread to other facilities and the entire NAVSEA.

Joint efforts and comparisons with other providers of similar services to the US military such as Raytheon, Lockheed Martin, Naval Air Systems Command Depots and Northrop Grumman speeded up the learning about the LSS concept implementation.

\section{The development of the highest level of maintenance, overhaul and modernization of the facilities}

In the Norfolk Naval Shipyard (NNSY), the Lean team applies the LSS concept to three completely different working models.

The first model consists of "background drives" which encompass classical machining and repair of components as well as services / protection by applying coatings. This model is more than a classic application of Lean techniques and tools. The work is executed by workforce organized into related units (cells).

The second model includes transaction-type activities whose main function (supply and delivery) is to support the vital mission of the work process. Thousands of technical drawings and work instructions, hundreds of thousands of spare parts and pieces are needed per year as support to mechanics in the right place and at the right time. Many other similar support processes also take advantage of the LSS methodology.

The third model refers to activities related to the deck and hull, which constitute the main task of the shipyard, and it significantly differs from the previous two, since hundreds of resources must move effectively on a daily basis through a very different scope of demands required for the five major ship classes. The fact that core processes and support processes result in the delivery of the right product, at the right time and the right place with the required quality makes this segment of work in the NNSY full of responsibility. It is important that all employees in the NNSY realize that their job is to support the fleet of ships and finish (deliver) complex work on schedule, with quality at the source and within the approved budget. They are helped by the LSS tools and methods to improve results in all three areas.

For the aircraft carrier Harry S. Truman (CVN-5, Figure 7), a major requirement for an overhaul in the NNSY has been recently completed. 


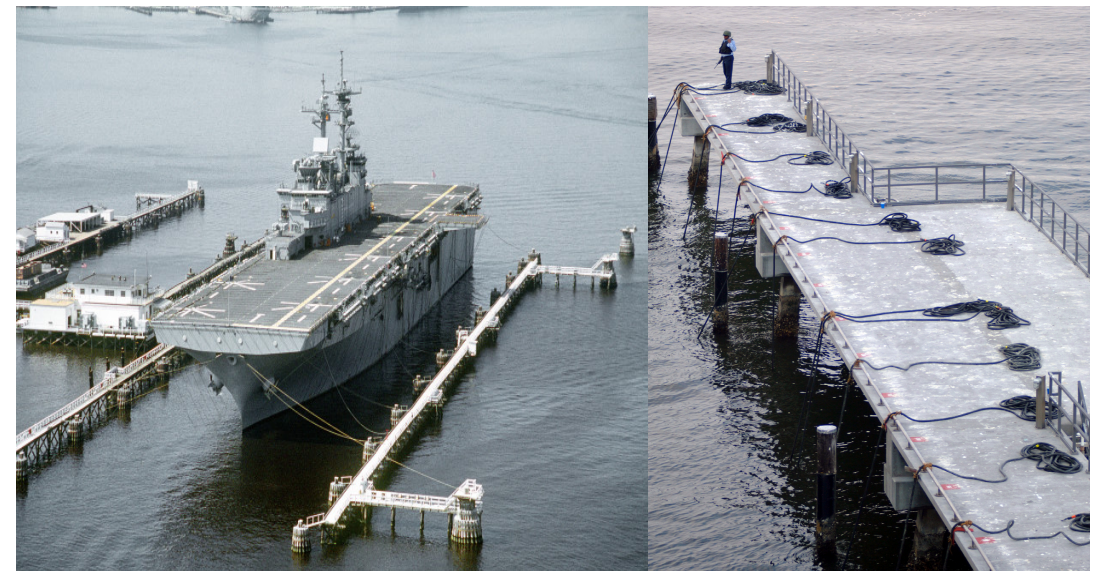

Figure 7 - An aircraft carrier is connected to electrical cables in the port due to the removal of a magnetic field (time saving)

(http://www.maritimequest.com/warship_directory/us_navy_pages)

Puc. 7 - Авианосец привязан к причалу электрическим проводом для размагничивания (экономия времени)

(http://www.maritimequest.com/warship directory/us navy pages)

Slika 7 - Nosač aviona povezan na električne kablove u pristaništu zbog uklanjanja magnetnog polja (ušteda vremena)

(http://www.maritimequest.com/warship_directory/us_navy_pages)

The project team with their co-workers (subcontractors), supported by yellow and black belt carriers in the NNSY, received that request and developed a plan for the improvement of prices, quality and safety, using the LSS tools, methods and techniques, even before the aircraft carrier came for repair. During more RIEs, they managed to complete the reengineering process for the removal of the main shaft and the installation, which reduced the number of people involved for 1,000 per day during the assessment process (inspection and defectation). This allows the user to increase the amount of work required when selecting the NNSY for a contractor.The RIEs team in the NNSY cooperate with other naval shipyards such as Puget Sound in order to provide double application of best practice and innovations.

\section{The inclusion of soldiers from combat units and junior officers in the Navy of the United Kingdom}

Military personnel on the front line are particularly focused on and interested in improvements. When not in combat, they work on improvements every day (Wetekam, 2006). Mapping the road to the creation of value, a spaghetti diagram and other Lean tools were used to 
detect losses in steps and time in different areas of a career. One of the improvements is the realization that the carrier deck can hold no more than 9 Harrier jets simultaneously in order to allow each of them to move independently. Earlier, more than 16 jets of this type were on the deck, under the assumption that this number may be even higher. The application of Lean showed that this was not the case. Standardized work has become a goal and a reality in many work areas. Everything that is an output of the aviation industry, the design of hangars or workshops for aircraft armament (shortening of the time to prepare air bombs by $80 \%$ ) was evaluated for the purposes of eliminating losses. Quite simple, lowtech solutions such as painting the positions for tool shelves helped improving the flow. When lifting an aircraft in order to repair its fuselage, employees learned how to reduce the operator error by $84 \%$ and reduce the repair time by lifting the aircraft for $37 \%$ (Figure 8 ).

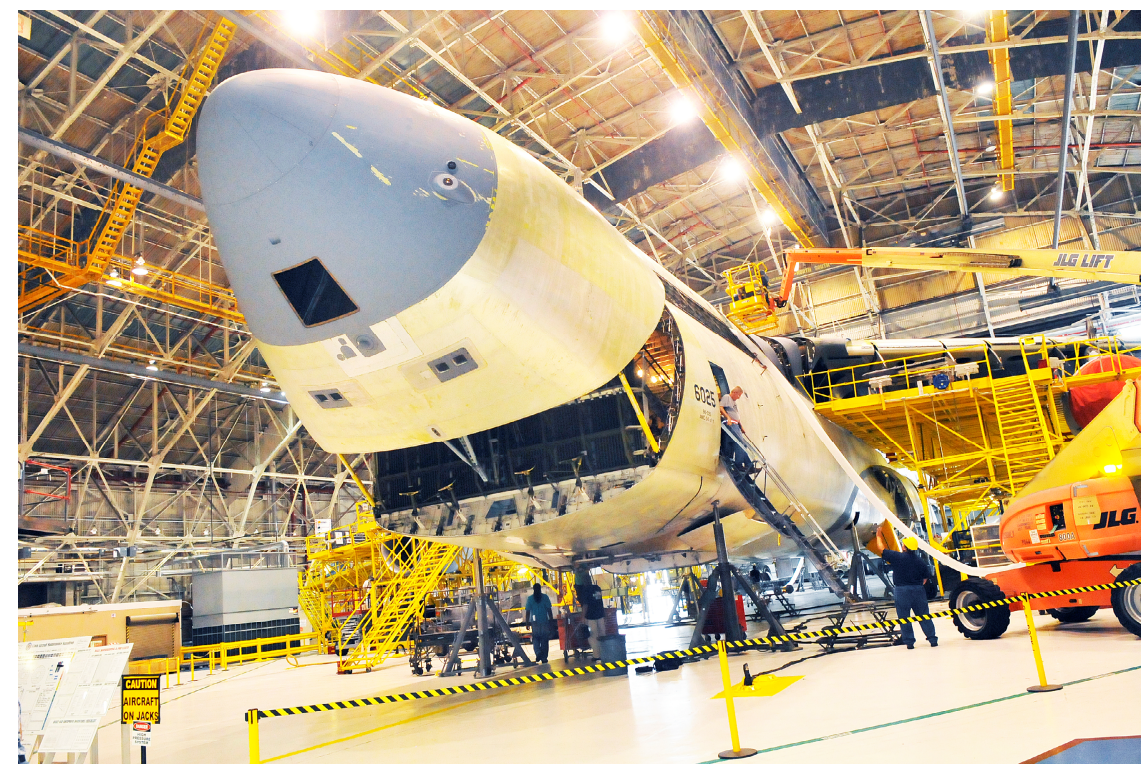

Figure 8 - The highest programmed level of the $\mathrm{C}-5$ aircraft maintenance in RAFB Puc. 8 - Высший запрограммированный уровень содержания самолета C-5 в RAFB Slika 8 - Najviši programirani nivo održavanja vazduhoplova C-5 u RAFB

Due to the increasing number and scope of activities, the Air Management Organisation (AMO) developed a mission planning department and a sector dealing with squadron operations. The work standardization and working space optimization helped in reducing planned activities that do not bring value (by 50\%) and created more flight activities that bring value. Even the dining room underwent a Lean analysis, which led to a reduction in waiting times. 


\section{Improving the highest level of maintenance of combat systems in the Red River Army Depot}

The Red River Army Depot (RRAD) is a facility for the highest and most complex level of maintenance of a large part of military equipment in the USA Army. It is a part of the command for armored vehicles and weapons. The RRAD has the task of maintaining the highest level of the entire fleet of vehicles and the missile shelf-life extension.

In the RRAD, mechanics working alongside engineers, technicians and managers managed to increase productivity from five vehicles (small size vehicles) per month to 16 vehicles per month, using the LSS tools. The labor cost is reduced by half as a result of shortening the previous length (13 miles) of the total travel process (spare parts, work at different locations) for more than $70 \%$. A Lean tool, the Spaghetti diagram, helped in recognizing the excess travel and consolidating the process into the flow process.

Another example of a successful application of the LSS concept in the RRAD is the reduction of the repair cycle time of the light multipurpose tactical truck (HEMTT, Figure 9), from an average of 120 days to 30 days.

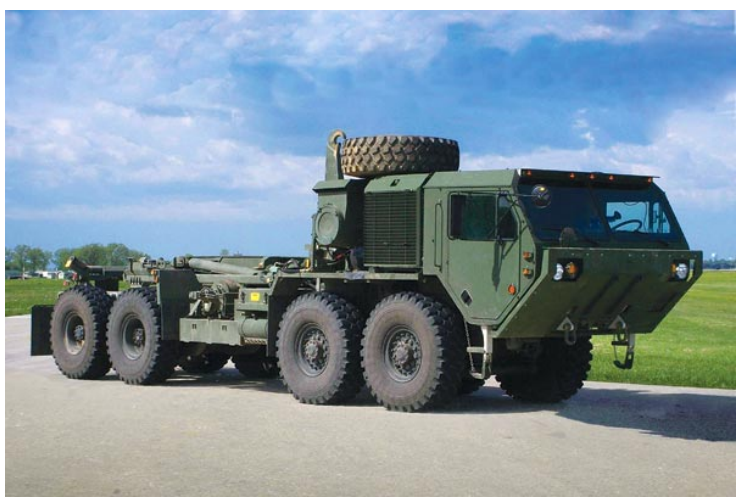

Figure 9 - Light multipurpose tactical truck (HEMTT)

Puc. 9 - Многоцелевой транспортный автомобиль тактического назначения (HEMTT) Slika 9 - Laki višenamenski taktički kamion (HEMTT)

Over a period of 15 months, there were several RIEs with a focus on the elimination of losses from the process in order to consolidate operations, make standard and balanced flow unities and establish visual inspection. A conversion of the accumulated process of performing operations into the form of flow had a significant impact. A better organization of the shop floor also led to the reduction of the HEMTT repair cycle time: placing necessary tools next to workers; correction; proper adjustment; scrubbing and cleaning; standardization; and a focus on safety. 


\section{Lean improvement in the accounting and financial activities in the Coast Guard of the United States}

In the financial center of the USA Coast Guard as well as in many institutions of this type, there are often queues, backlogs and errors in accounting operations, as in any factory, due to millions of different payment activities per year. Since the LSS concept had been successfully applied in other military activities, the Financial center decided to start the journey of learning and applying the LSS techniques in financial accounting and transactions. All 525 employees have undergone the initial training for the LSS. In addition, first-level controllers in accounting operations had an eight-hour tour of the factory, a manufacture-related simulation and other trainings. The goal is to unite all the accounting payment processes in one, more uniform process.

\section{Suggestions for applying the Lean Six Sigma concept in the Serbian Army and the Ministry of Defence}

In the Serbian Army (VS) and the Ministry of Defence (MO) of the Republic of Serbia, there are positive examples of significant progress in the transformation of certain processes, so that the user (the whole defense system) can satisfy its requirements in an efficient manner. The intensity and extent of these changes are not in line with modern trends and requirements imposed by similar processes in other organizational systems and armies in the region.

Problems and resistance to the improvement of processes in the VS and the MO occur mostly because there is no strong and clear commitment to effective and efficient changes either with the leadership or process executors. There is not enough knowledge about the possibilities of modern concepts of process management in organizational systems, whatever they may be called, because there is no necessary exchange of information and experiences with the outside world, there is no comparison with the best in the profession (benchmarking) and trading in knowledge. This is due to saving on education and training, in line with the general tendency of treating education as cost, rather than looking to profit from that investment in a longer period of time.

Examples from the VS and MO practice, given below, have been recognized as a good basis to start improvements using the LSS concept; in all cases, it is necessary for the whole system to be committed to transformations of key processes in the VS and the MO, 
based on the same concept. Introducing the concept to all employees is the next step, together with their motivation and continuous training of many years in order to obtain a quality product or service tailor-made for the defense system, within the designed limits.

\section{Administrative tasks}

Serbian army is a hierarchical complex system with many types of administrative models, procedures, forms for the same activity that takes place in different organizational units. This diversity makes it difficult for daily administration activities and operational work of the whole system, as well as for standing up for personal and business rights of individuals. There are improvements in the system development and upgrading, but bureaucratization prevails because of the resistance and different interpretations and applications of prescribed procedures. There should be a strategic commitment by the top management to make the administration system more effective and efficient through systematically breaking old habits, starting the analysis from the top downwards, finding redundant activities and patterns, defining the shortest flows of information, encouraging employees to propose changes and applying and adopting best practices on a daily basis.

\section{Overhaul of technical systems of special purpose}

The Serbian Army has overhauling institutions responsible for maintaining the highest level of its technical systems of special purpose (TSSP). Years of analyses have shown that there are various problems in their work, mostly organizational, conceptual and technological ones. That is why processes in overhauling institutions represent a great potential for improvement on the basis of the model shown in (Marić, 2010).

\section{Maintenance of technical systems of special purpose}

TSSP maintenance occupies most of their life cycle and requires significant financial means. In the TSSP maintenance theory and practice, there is a long battle for the level of optimization of TSSP maintenance costs and reliability. Maintenance management based on the model shown in (Epler, Andrejić, 2014) and (Epler, 2013, pp.121-137), can increase the effectiveness and efficiency of TSSP maintenance, without compromising maintenance quality. 


\section{Military Nutrition in the Serbian Army}

In the cadet restaurant at the Military Academy, there has been an infrastructural and organizational disbalance in the capacities for the preparation and distribution of food, which makes the cadet feeding system unprofitable. The existing capacities were designed to enable the preparation and distribution of $40 \%$ more meals than the real needs are, which is, economically speaking, an unnecessary financial burden on the limited funds allocated for this purpose. In terms of meeting the economic requirements, it is possible to reduce or completely eliminate the negative effects of excess capacities by finding them other purposes or by finding alternative ways to organize nutrition at the Military Academy in a more rational way (Arsić, 2014, pp.168-186). With the support and commitment of the top management to improve business dealings in this area, the analysis given here provides a good basis for a successful transformation based on the LSS principles.

\section{Material and financial operations}

Material supply chain management in the Serbian Army is an area which has not experienced any improvement for many years, although there are daily numerous problems that the system neither answers, nor reacts to (incomplete and inefficient nomenclature of materiel, excess and inefficient documentation for disposition, the lack of a unified information system, etc.). The whole process should be fully analyzed and designed for the future in order to improve the existing situation using modern management methods, tools, techniques and IT support.

The parallel codification system of material resources (http://www.dskm.mod.gov.rs/sr/nato-kodifikacija/prednosti-kodifikacije), developed and introduced by the Directorate for Standardisation, Codification and Metrology of the Ministry of Defence of the Republic of Serbia represents a good start for the LSS quality transformation of materiel management in the Serbian Army which has thousands of various TSSP and milions of different spare parts and other materiel which has to be identified and delivered on time in required quantities.

Financial operations and the procurement process in the Serbian Army represent a regulated system with a daily circulation of a large number of various payment documents which might be consolidated and unified. Public procurement procedures are also very complex and often slow down and hinder the execution of core processes. Financial operations in the Serbian Army represent an area suitable for a transformation on the LSS principles. 


\section{Training, education and further training}

In recent years, training of the Army of Serbia personnel has been unified and coordinated, which makes it high quality, more effective and more efficient. The Command for Training and the Directorate for Training and Doctrine of the SAF Headquarters (J-7) should make a VSM for the whole process of training, with the aim of detecting bottlenecks and their elimination on the basis of LSS.

Graduate and postgraduate levels of education at the University of Defence are in the process of harmonization with the global trends in the higher education system of the Republic of Serbia. Everyday processes that accompany education are often slow, complicated and do not go to meet the users, i.e. students and trainees. The whole process of higher education at the University of Defence should be visible from the enrollment to the graduation; appropriate methods, techniques and tools should be applied in order to make the system customer-focused, with higher quality and efficiency. A model presented in literature (Radošević, 2013) can help improving the education process.

\section{Conclusion}

Defects or losses are a common feature for different organizational systems providing either products or services, as well as for different processes in an organizational system. They are the ones that cause refinement, scrap, extra work of employees, increasing costs, etc. Identifying and preventing the appearance of defects or losses and their efficient and effective removal will reduce workload and costs of the process, so that available resources can be used for other investments and possible expansion of the scope of work.

Past decades of application of classical concepts and models of management of organizational systems and processes to achieve greater effectiveness and efficiency (reduction of cycle time, increasing the volume and intensity of work, hiring new people, buying more machines, analysis of gains but not losses in processes, planning without taking into account the constraints, etc.) have not brought results in organizational systems, no matter which activity they deal with.

In addition, modern business conditions, high and varied requirements of customers and users pose new and complex demands to production and service systems (companies) so that, if they want to play a part on its core business market, they must be focused on customers and strive to achieve business excellence, i.e. the quality at the source. Responses to new circumstances imposed by contemporary conditions can be found in the LSS concept of managing organizational systems. 
The Lean Six Sigma concept requires continuous improvements in the organizational system, involvement of all employees in the work on improvements and changes throughout their teamwork on the measurement and systematization of processes, reduction of deviations in product quality or process duration, reduction of product defects, and everything else that can make this process of better quality and more valuable. Continuous improvement is not easy to achieve, but it is the only way to survive in the market.

The Lean Six Sigma concept has many advantages compared to other well-known concepts for improving management of organizational systems. The concept of Six Sigma focuses on quality, not on the process speed in the organizational system. The concept of Lean is better at improving speed than quality. It is therefore not surprising that the practice merged these two concepts of the management of complex and significant organizational systems that will operate on the principle of carrying out the best work in the best possible way.

Taking into account the available literature and everything said so far about the LSS concept of managing organizational systems, it can be said that the LSS management concept is the synthesis and upgrade of management in the most important elements of the organizational system, namely the concept and the organization.

The Lean Six Sigma concept of managing organizational systems represents a standardization of the proven best practices of process management through the introduction of new techniques, methods and tools. The comprehensiveness of its fundamental principles, tools, and application effects is what makes the LSS ideal for use in all types of companies i.e. organizational systems regardless of their core business and size.

The Lean Six Sigma management concept has proven its worth, as stated in the mentioned literature sources. Buyers of goods or service users get a better product or service and they become more loyal to the manufacturer or service provider. Prices are falling.The application of the LSS concept requires time, effort and money.

The Lean Six Sigma transformation in the armies around the world is sorting and cleaning equipment and optimizing inventories. This involves teaching managers, mainly by experts in this field outside the system of defense, how to see processes more clearly and comprehensively, with the aim of initiating a change in thinking and action (cultural change). First of all, it is necessary to initiate such a challenge, to invest in the training of young decision-makers, and then all the employees, because their knowledge, energy and persistence will be crucial on the long road to success and transferring the initiative to all partners and subcontractors of the army outside the military system. By applying the LSS concept of process management, troop military units would probably reach the same level of readiness with more rational and efficient 
engagement of resources. Service providers in the army and their subcontractors outside the defense system would greatly increase efficiency and productivity, which would certainly contribute to their competitiveness in the domestic and international market.

There are numerous examples from the practice of the VS and the MO that can serve as a good basis to start improvements based on the proven LSS concept, which requires a commitment to system transformation, perseverance along the way, getting to know the goal, motivation of all employees, training, and long-term continuous work.

Such a systematic approach to the management of the above functions and processes in the VS and the MO, through the transparency of its results, will have a positive impact on the rest of the civil service and will make the state more successful, more effective and more efficient.

\section{Literatura}

Arsić, S. 2014. Mogućnost unapređenja sistema ishrane na Vojnoj akademiji ekonomski aspekt / Possibilities for improving the food system at the Military Academy: Economic aspects. Vojnotehnički glasnik / Military Technical Courier, 62(4), pp.168-186.

Epler, I., \& Andrejić, M. 2014. Lean koncept kao osnova održavanja tehničkih sistema specijalne namene u Vojsci Srbije. In: ICDQM 2014, Beograd.

Epler, I. 2013. Analiza mogućnosti primene modela održavanja prema stanju na primeru tenkovskog naoružanja / Analysis of the possibility of applying a condition-based maintenance model on an example of tank weapons. Vojnotehnički glasnik / Military Technical Courier, 61(4), pp.121-137.

Goetsch, S.B., \& Davis, S.B. 2006. Quality management: Introducion to Total Quality Management for production, Processing and Services.New Jersey: Prentice Hall.

Lazić, M. 2006. Alati, metode i tehnike unapređenja kvaliteta.Kragujevac: Mašinski fakultet.

Marić, B. 2010. Model upravljanja proizvodnim procesom u remontno - proizvodnim sistemima na bazi Lean koncepta.Istočno Sarajevo: Mašinski fakultet.

Radošević, M. 2013. Lean koncept u obrazovnim sistemima.Novi Sad: Fakultet tehničkih nauka.

Rajković, V. 2012. Lean Six Sigma, [Internet], Available at:

http://www.cqm.rs/2012/cd1/pdf/39/05.pdf, Retrieved: 20.04.2015.

Retrieved from http://www.maritimequest.com/warship_directory/us_navy_pages

Wetekam, D. 2006. Review article. In: AME's 2006, Annual conference, Dallas, TX.

\section{РЕАЛЬНЫЕ ПРОЦЕССЫ СОВЕРШЕНСТВОВАНИЯ В ВООРУЖЕННЫХ СИЛАХ НА ОСНОВАНИИ LEAN SIX SIGMA КОНЦЕПТА}

Игорь Й. Эплер ${ }^{a}$, Ранко Ц. Божичкович ${ }^{6}$, Славиша Н. Арсич ${ }^{a}$, Елена Б. Динич ${ }^{a}$ а Университет обороны в Белграде, Военная академия,

г. Белград, Республика Сербия

${ }^{\sigma}$ Университет в Восточном Сараево, Факультет транспорта, Восточное Сараево, Республика Сербская, БиГ 
ОБЛАСТЬ: логистика (организация, экономия, менеджмент в логистике) ВИД СТАТЬИ: профессиональная статья ЯЗЫК СТАТЬИ: английский

\section{Резюме:}

Готовность к вызовам и переменам, повышение качества продукции или обслуживания с использованием меньшего количества ресурсов, а также довольный потребитель это важнейшие постулаты в области промышленного производства. Данные правила, в целях развития и совершенствования своей сложной и ответственной деятельности и достижения большей эфрфективности, приняло и военное руководство во всем мире. В данной работе представлен обзор осуществленных трансорормаций в вооруженных силах Соединенных Штатов Америки (США), относящихся как к военнослужащим, так и поставщикам и другим сотрудникам. B статье также описаны положительные результаты внедрения современного концепта управления процессами, такие как повышение качества и снижение расходов в разных областях деятельности. В заключениистатьи выносятся предложения по внедрению подобной модели управленческих процессов в вооруженных силах Республики Сербия.

Ключевые слова: lean, поставщики, военный, руководитель, пользователь, область.

\section{REALNI PROCESI UNAPREĐENJA U VOJSCI NA OSNOVAMA} KONCEPTA LEAN SIX SIGMA

Igor J. Epler ${ }^{a}$, Ranko C. Božičković ${ }^{b}$, Slaviša N. Arsića , Jelena B. Dinića a Univerzitet odbrane u Beogradu, Vojna akademija, Beograd, Republika Srbija

${ }^{b}$ Univerzitet u Istočnom Sarajevu, Saobraćajni fakultet, Istočno Sarajevo, Republika Srpska, BiH

OBLAST: logistika (organizacija, ekonomija, menadžment u logistici) VRSTA ČLANKA: stručni članak JEZIK ČLANKA: engleski

\section{Sažetak:}

Spremnost na izazove i promene, stvaranje više dobara ili usluga sa manje resursa, usmerenje na kvalitet i na korisnika predstavljaju jedne od najvažnijih oblastii delovanja industrijskih proizvođača, a koje su vojni rukovodioci u vojskama širom sveta, po uzoru na njih, razvili sa svojim pripadnicima i snabdevačima, u težnji da celokupan, veoma složen i značajan rad učine efikasnijim i efektivnijim. 
$U$ članku se daje pregled dostignutih transformacija u vojsci Sjedinjenih Američkih Država (USA), kod njenih pripadnika, snabdevača i saradnika, gde se implementacijom savremenih koncepcija upravljanja procesima došlo do značajnih unapređenja i ušteda u raznim oblastima. Na kraju rada predložena su unapređenja u srodnim oblastima u Vojsci Srbije, primenom navedenih uspešnih modela upravljanja procesima.

Ključne reči: lean, snabdevači, vojni, rukovodilac, korisnik, oblast.

Paper received on / Дата получения работы / Datum prijema članka: 09. 05. 2015.

Manuscript corrections submitted on / Дата получения исправленной версии работы / Datum dostavljanja ispravki rukopisa: 27. 06. 2016.

Paper accepted for publishing on / Дата окончательного согласования работы / Datum konačnog prihvatanja članka za objavljivanje: 29. 06. 2016.

(C) 2016 The Authors. Published by Vojnotehnički glasnik / Military Technical Courier (www.vtg.mod.gov.rs, втг.мо.упр.срб). This article is an open access article distributed under the terms and conditions of the Creative Commons Attribution license (http://creativecommons.org/licenses/by/3.0/rs/).

() 2016 Авторы. Опубликовано в "Военно-технический вестник / Vojnotehnički glasnik / Military Technical Courier" (www.vtg.mod.gov.rs, втг.мо.упр.срб). Данная статья в открытом доступе и распространяется в соответствии с лицензией "Creative Commons" (http://creativecommons.org/licenses/by/3.0/rs/).

(c) 2016 Autori. Objavio Vojnotehnički glasnik / Military Technical Courier (www.vtg.mod.gov.rs, втг.мо.упр.срб). Ovo je članak otvorenog pristupa i distribuira se u skladu sa Creative Commons licencom (http://creativecommons.org/licenses/by/3.0/rs/). 